\title{
Relationship Of Exclusive Breastfeeding Of Frequency Of Illnes Events In Baby Age 6-12 Months In Community Health Centers Banyumas
}

\author{
Wuri Utami, Hastin Ika Indriyastuti, Yuliawati \\ STIKES Muhammadiyah Gombong \\ *utamiwuri@gmail.com
}

\begin{abstract}
Coverage of exclusive breastfeeding in Banyumas puskesmas is only $28.47 \%$. This figure is still far from the target of exclusive breastfeeding coverage in Banyumas Regency which is $65 \%$. Exclusive breastfeeding is an effort to increase the baby's immunity in order to avoid infectious diseases. The purpose of this study is to determine the relationship of exclusive breastfeeding to the frequency of illness in infants aged 6-12 months in Banyumas Health Center. This research method is using quantitative research methods with observational analytic research with a retrospective cohort approach. The number of samples is 162 respondents. The measuring instrument used was a questionnaire. Data analysis using statistical tests with chi-square test. The results showed the majority of infants who were given exclusive breastfeeding experienced a frequency of rare illness events as many as $59(72.8 \%)$ respondents and infants who were not given exclusive breastfeeding the majority experienced frequent frequency of illness events as many as 50 $(61.7 \%)$ respondents. The analysis of the study showed that there was a relationship between exclusive breastfeeding and the frequency of illness in infants aged 6-12 months in Banyumaspuskesmas ( $p=.000<0.05$ ). In this study it was found that the majority of the incidence of illness in infants who were given exclusive breastfeeding was fever as much as $22(27.2 \%)$ while infants who were not exclusively breastfeeding were diarrhea as much as $37(45.7 \%)$.
\end{abstract}

Keywords: Frequency of illness, Exclusive Breastfeeding, Baby 


\section{STRADA Jurnal Ilmiah Kesehatan}

DOI: $10.30994 /$ sjik.v9i2.311

ISSN: 2252-3847 (print); 2614-350X (online)

Vol.9 No.2 November 2020 Page.381-391

STRADA Jurnal Ilmiah Kesehatan, its website, and the articles published there in are licensed under a Creative Commons Attribution-ShareAlike 4.0 International License.

\section{BACKGROUND}

The baby is the stage of human development after birth (Puspita, 2010 in Mujib, 2018). Immunity at this age is not yet perfect, so there is still a range of various viruses and bacteria that can interfere with health (Central Statistics Agency, 2018). One of the efforts to increase body immunity in infants is breastfeeding. ASI (Breast Milk) is a living liquid which contains white blood cells, immunoglobulins, enzymes and hormones, as well as specific proteins, and other nutrients needed for children's growth and development (Ministry of Health, Republic of Indonesia, 2015). The composition contained in breast milk, one of which is that there are immune substances so that in addition to being a nutrient for infants, breast milk can also provide protection to infants from disease.

In 2002, Word Health Organization (WHO) and United Nations Children's Fund (UNICEF) developed a global strategy for infant and child feeding, one of which was exclusive breastfeeding for 6 months (Nurlaila, Utami, \&Cahyani W, 2018). Exclusive breastfeeding is giving only breast milk to babies from birth to 6 months without giving food and other drinks, except drugs and vitamins (WHO, 2020).

Based on WHO data (2018), the average number of exclusive breastfeeding in the new world is around $41 \%$. Nationally, the coverage of infants receiving exclusive breastfeeding in Indonesia in 2018 is $68.74 \%$. Based on data from the Health Profile of Banyumas Regency in 2018, the coverage of exclusive breastfeeding in Banyumas Regency is $66.1 \%$. While exclusive breastfeeding coverage at Banyumas Health Center is $71.4 \%$. This figure has exceeded the target of exclusive breastfeeding coverage in Banyumas Regency, which is $65 \%$. But in 2019 the coverage of exclusive breastfeeding at the Banyumas Health Center is only $28.47 \%$. This figure is greatly decreased when compared to 2018, which was 71.4\% (Banyumas District Health Office, 2019).

Based on the results of research Ara (2018) shows that there are differences in the proportion of infant immunity status based on breastfeeding, namely babies who are not exclusively breastfed at a risk of 2,180 times having an unfavorable immune status. While the results of Fadhilah's research (2018) show that children who get exclusive breastfeeding have the opportunity to reduce the incidence of infectious disease 2.00 times greater than non-exclusive breastfeeding.

Preliminary study at the Banyumas Health Center in December 2019, by conducting interviews about exclusive breastfeeding and frequency of illness for 5 mothers who examined their babies aged 6-12 months, obtained data that 3 mothers said to give exclusive breastfeeding and the frequency of illness in the baby in the last three months is $\leq 2$ times. Whereas 2 mothers who said they did not give exclusive breastfeeding, the baby experienced pain $>2$ times. The pain experienced by these babies is an infectious disease including fever, cough and flu. Based on these problems, it is necessary to conduct research on "The Relationship of Exclusive Breastfeeding to the Frequency of Pain in Infants 6-12 Months in Banyumas Health Center".

\section{METHOD}

This research method is using quantitative research methods with observational analytic research with a retrospective cohort approach. This research was conducted online via WhatsApp on April 28, 2020 - May 13, 2020 by providing a google form link containing a questionnaire. The place of this research is in the working area of BanyumasPuskesmas located in the highlands and lowlands, namely Binangun Village, 


\section{STRADA Jurnal Ilmiah Kesehatan}

DOI: $10.30994 /$ sjik.v9i2.311

ISSN: 2252-3847 (print); 2614-350X (online)

Vol.9 No.2 November 2020 Page.381-391

Pasinggangan Village, Karangrau Village, Kedunguter Village, Sudagaran Village, and Pakunden Village.

The study population was all mothers in Banyumas Health Center who had babies aged 6-12 months as many as 443 people with a study sample of 162 respondents. Sampling uses purposive sampling and cluster sampling methods, because it sees a wide population spread in villages in the highlands and lowlands. The sample in this study consisted of two groups, namely groups of mothers who gave exclusive breastfeeding and not exclusive breastfeeding to their babies who met the inclusion criteria. Each group numbered 81 respondents.

The inclusion criteria in this study were mothers who had babies aged 6-12 months, mothers and infants registered at BanyumasPuskesmas, babies of normal birth weight (2.5$4 \mathrm{~kg}$ ), infants received complete basic immunizations according to the age-based delivery schedule, mothers who have cellphones (cellphones) that support in filling out the questionnaire via Google form, and mothers who are willing to be respondents.

This research instrument used a questionnaire exclusive breastfeeding and the frequency of illness. Data analysis used was univariate analysis in the form of frequency distribution and bivariate analysis using chi-square test. This research has received a letter of ethics test from STIKES Muhammadiyah Gombong.

\section{RESULT}

Univariate Analysis Results

a. Characteristics of Respondents

Frequency Distribution of Characteristics of Infants Mothers Aged 6-12 Months at Banyumas Health Center in $2020(\mathrm{n}=162)$

Based on the frequency distribution of respondents' characteristics, it was found that the age of mothers who gave exclusive and non-exclusive breastfeeding, the majority were aged 20-35 years with a total of $73(90.1 \%)$ respondents and $65(80.2 \%)$ respondents, respectively. The education of mothers who give exclusive breastfeeding is mostly junior high school graduates, $32(39.5 \%)$ respondents, and not exclusively breastfeeding, the majority are senior high school graduates, $35(43.2 \%)$ respondents. Occupation of mothers who give exclusive breastfeeding and not exclusive breastfeeding the majority do not work respectively $74(91.4 \%)$ respondents and $63(77.8 \%)$ respondents.

b. Frequency Distribution of Exclusive Breastfeeding for 6-12 Months Infants at the Banyumas Health Center in $2020(n=162)$

Based on the frequency distribution of exclusive breastfeeding, the data is halfof the total respondents gave exclusive breastfeeding to their babies that is equal to $81(50.0 \%)$ of respondents.

c. Distribution of Frequency of Illness Occurrence in Infants 6-12 Months at the Health Center Banyumas in $2020(n=162)$

Based on the distribution of the frequency of illness, it was obtained that the frequency of illness in infants aged 6-12 months in the Banyumas Public Health Center that were given exclusive breastfeeding, the majority were rarely sick, namely $59(72.8 \%)$ respondents and the majority were not exclusively breastfeeding, which was often $50(61.7 \%)$ respondents.

Bivariate Analysis Results

The Relationship of Exclusive Breastfeeding to the Frequency of Sickness in Infants 6-12 Months at Banyumas Health Center in $2020(n=162)$

Based on the results of bivariate research, it was obtained data that the majority of infants given exclusive breastfeeding experienced the frequency of infrequent illness events as many as 59 (72.8\%) respondents and infants who were not given exclusive breastfeeding the majority 


\section{STRADA Jurnal Ilmiah Kesehatan}

DOI: $10.30994 /$ sjik.v9i2.311

ISSN: 2252-3847 (print); 2614-350X (online)

Vol.9 No.2 November 2020 Page.381-391

experienced the frequency of illness events which were often as many as $50(61.7 \%)$ respondents , and based on the calculation of the chi-square test, the value of $p=.000<0.05$ means that there is a relationship between exclusive breastfeeding and the frequency of illness with a RR value of 1.903. From this description it can be seen that $\mathrm{Ha}$ was accepted showing that there is a relationship between exclusive breastfeeding and the frequency of illness occurrence in infants aged 6-12 months in Banyumas Health Center.

\section{DISCUSSION}

1. Univariate Variables Include Mother Baby Characteristics Include (Age, Education, and Occupation), Exclusive Breastfeeding, and Frequency of Illness.

a. Age

Based on the results of the study obtained data that the age of mothers who give exclusive breastfeeding and not exclusive breastfeeding the majority aged 20-35 years with the number of $73(90.1 \%)$ respondents and $65(80.2 \%)$ respondents, respectively. In theory, maternal age can affect exclusive breastfeeding for her baby, because with increasing age the power of capture and mindset will increase which can give birth to knowledge and a good attitude so that the success of exclusive breastfeeding can be achieved. As Istianah (2010) argues in Mindarsih (2018) that the more a person ages, the more his comprehension and mindset will increase so that his attitude and knowledge will be better. Based on the opinion of Notoatmodjo (2010) in Nurbayanti (2016) that someone's age is closely related to knowledge.

Age 20-35 years is an adult age. In the opinion of Perry \& Potter (2013) in Widianty (2019) that adulthood is a time when someone is considered mature, both physiologically, psychologically, and cognitively. At this age mothers are generally more active in seeking various information, especially on how to breastfeed, how long they should breastfeed their babies and other information that can support the success of mothers in exclusive breastfeeding.

In this study shows that there is no difference between the age of the mother with exclusive breastfeeding, even though the majority of the mother's age is in adulthood where at this age mothers should be more actively seeking various information, especially about exclusive breastfeeding that can support the success of mothers in exclusive breastfeeding but because there are other factors one of which is the lack of motivation of mothers in exclusive breastfeeding, so the success of mothers in exclusive breastfeeding is hampered. As Hanifah argues (2015) that the factors that influence mothers at the age of 20-35 years who do not give exclusive breastfeeding are low motivation of mothers in exclusive breastfeeding.

b. Education

Based on the results of the study found that the education of mothers who give exclusive breastfeeding the majority of junior high school education is $32(39.5 \%)$ respondents, and not exclusively breastfeeding the majority of high school education is 35 (43.2\%) respondents. In theory, education can affect exclusive breastfeeding because the higher the level of one's education, the easier it will be to receive information that can affect one's attitude. As Haryono (2014) argues in Savitri (2018) that education is one of the factors that make it easier in an effort to increase the behavior of exclusive breastfeeding in which education that has been obtained affects the knowledge and attitudes of a person. Sihombing research (2018) shows that there is a significant relationship between maternal education and exclusive breastfeeding $(\mathrm{p}=0.003<0.05)$, where the majority of highly educated mothers give exclusive breastfeeding to their babies, namely $13(76.5 \%)$ respondents, and the majority of mothers with basic education do not give exclusive breastfeeding to their babies, which is $9(75.0 \%)$ respondents. In this study showed that the majority of mothers who gave exclusive breastfeeding were junior high school graduates, $32(39.5 \%)$ respondents, and not exclusively breastfeeding, the majority of those with high 


\section{STRADA Jurnal Ilmiah Kesehatan}

DOI: $10.30994 /$ sjik.v9i2.311

ISSN: 2252-3847 (print); 2614-350X (online)

Vol.9 No.2 November 2020 Page.381-391

school education were $35(43.2 \%)$ respondents. This can occur because there are other factors that affect the mother of the baby in exclusive breastfeeding, one of which is the experience of both the mother herself and others. According to Mulyani and Astuti (2018) that breastfeeding experience has a positive relationship between the duration of breastfeeding in the previous child and the current child, if the mother gives exclusive breastfeeding to the previous child then it tends to give exclusive breastfeeding also to the next child. In addition, family culture also affects exclusive breastfeeding, if the parents do not give exclusive breastfeeding, it will put pressure on their children not to give exclusive breastfeeding.

c. Based on work

Based on the results of the study found the majority of mothers not working with those who give exclusive breastfeeding by 74 (91.4\%) of respondents and non-exclusive breastfeeding the majority of $63(77.8 \%)$ respondents. In this study shows that there is no difference between work and exclusive breastfeeding. This happens because there are other factors that influence mothers in exclusive breastfeeding including lack of knowledge, milk production, and family support. As Hanifah (2015) argues that mothers who do not work do not give exclusive breastfeeding due to other factors including lack of knowledge related to exclusive breastfeeding, less milk coming out, and the lack of family support in exclusive breastfeeding. Research conducted by researchers in line with research Hanifah (2015) showed that mothers who did not give exclusive breastfeeding mostly did not work as many as 24 (66.7\%) respondents. This study is also in line with research Ara (2018) shows that the majority of mothers who give exclusive breastfeeding and not exclusive breastfeeding do not work respectively 57 (91.9\%) respondents.

d. Exclusive breastfeeding

Based on the results of the study that mothers who gave exclusive breastfeeding and not exclusive breastfeeding were $81(50.0 \%)$ respondents respectively. The results of this study showed that the majority of infants who were given exclusive breastfeeding experienced a frequency of rare illness events as many as $59(72.8 \%)$ respondents. This is because breast milk protects the baby from disease. As the opinion of Proverawati\&Rahmawati (2010) that breast milk protects babies from infectious diseases. According to Andriyani (2013) breastfeeding for infants can reduce the risk of experiencing various kinds of infections in the first year of life due to the process of transferring immune factors (immunity) in breast milk and colostrum (pre-milk) from mother to baby. Based on the results of research Ara (2018) shows that there are differences in the proportion of infant immunity status based on breastfeeding, namely babies who are not exclusively breastfed at a risk of 2,180 times having an unfavorable immune status. This study is in line with research conducted by Fadhilah (2018) which shows that there is a relationship between exclusive breastfeeding and a decrease in the incidence of infectious diseases with a value $(p=0,000<0.05)$ and a RR value of 2.00, which means infants who are exclusively breastfed are at risk of experiencing the incidence of infection is low 2 times greater than in infants who are not exclusively breastfed.

e. Frequency of illness

The frequency of illness in infants aged 6-12 months in BanyumasPuskesmas given exclusive breastfeeding, the majority were rarely sick, $59(72.8 \%)$ respondents and the majority of non-exclusive breastfeeding were often sick, namely $50(61.7 \%)$ respondents. The types of pain events examined in this study were diarrhea, ear infections, ARI, pneumonia, fever, and other infectious diseases. According to Proverawati\&Rahmawati (2010) the best nutrition for babies is breast milk. ASI can protect babies from infection (Proverawati\&Rahmawati, 2010). Research conducted by the Cleveland Clinic of the 


\section{STRADA Jurnal Ilmiah Kesehatan}

DOI: $10.30994 /$ sjik.v9i2.311

ISSN: 2252-3847 (print); 2614-350X (online)

Vol.9 No.2 November 2020 Page.381-391

United States states that in normal babies less than 1 year of age have an average of infectious diseases 6-8 times per year or 1-2 times in the last 3 months (Judarwanto, 2010 in Ara, 2018).

In this study, data were obtained that the majority of illnesses in infants given exclusive breastfeeding were fever as many as $22(27.2 \%)$ respondents while infants who were not exclusively breastfeeding were diarrhea as many as $37(45.7 \%)$ respondents. Fever in infants who are exclusively breastfed can occur due to dehydration, where the fever that occurs is a physiological response not a symptom of a disease caused by a virus or bacterial pathogen. Breast milk contains antibodies namely immunoglobulin (Ig) which can ward off microorganisms such as viruses, or pathogenic bacteria so that it can protect infants from infectious diseases (Narwastu, 2019). Fever that occurs in infants who are exclusively breastfed is only $22(27.2 \%)$ respondents. This shows that exclusive breastfeeding can reduce the incidence of fever in infants. As research conducted by Judge (2018) shows that there is a relationship between exclusive breastfeeding with a low frequency of occurrence of fever in infants $(p=0,000<0.05)$.

Infants who were not exclusively breastfed had the majority of diarrhea in 37 (45.7\%) respondents. This can occur due to lack of maternal hygiene in the preparation of milk or MPASI as well as the low immunity of the body in infants. Whereas babies who were exclusively breastfed had diarrhea only by $4(4.9 \%)$. This happens because breast milk is a nutritional intake that is safe for infants and can increase the baby's immunity. According to Singh (2017) that breast milk contains bioactive components that can prevent babies from diarrhea.

2. Bivariate Variables

The relationship between exclusive breastfeeding and the frequency of illness.

Based on the results of research at the Banyumas Community Health Center, data showed that infants aged 6-12 months who were given exclusive breastfeeding, the majority experienced a frequency of rare illness events as many as $59(72.8 \%)$ respondents and infants who were not given exclusive breastfeeding, the majority experienced frequent frequency of illness events 50 $(61.7 \%)$ respondents, and based on the chi-square test calculation, the value of $p=.000<0.05$, which means that there is a relationship between exclusive breastfeeding with the frequency of illness with a RR value of 1.903 , which means that babies who are exclusively breastfed have the opportunity to experience a rare frequency of illness is 1,903 times greater than for babies who are not exclusively breastfed. Breast milk contains antibodies namely immunoglobulin (Ig) which can ward off microorganisms such as viruses, or pathogenic bacteria (Narwastu, 2019). Colostrum is the first milk that comes out containing many antibodies, especially IgA which can help the body to fight infectious diseases such as pneumonia, these antibodies form a defense in parts of the body at risk of being attacked by pathogenic bacteria or viruses, namely mucous membranes in the throat, lungs, and intestines (Prasetyono, 2009 in Narwastu, 2019).

According to Proverawati\&Rahmawati (2010) that breast milk can protect babies from infection. According to UNICEF (2019) that babies who are not exclusively breastfed can have a greater risk of death from diarrhea or pneumonia than babies who are exclusively breastfed. Based on research conducted by Hardiyanti (2019) to children in PKU Muhammadiyah Gamping with a history of acute otitis media (OMA) associated with breastfeeding in children, it was found that there was a relationship between the incidence of acute otitis media with breastfeeding in children. Exclusive breastfeeding for more than 3 months reduces the risk of acute otitis media by 50\% (Hardiyanti, 2019).

\section{CONCLUSION}

1. Characteristics of the majority of mothers of infants aged 20-35 years as many as $73(90.1 \%)$ give exclusive breastfeeding and $65(80.2 \%)$ do not exclusively breastfeed. The majority of junior high school education was $32(39.5 \%)$ giving exclusive breastfeeding and high school as 


\section{STRADA Jurnal Ilmiah Kesehatan}

DOI: $10.30994 /$ sjik.v9i2.311

ISSN: 2252-3847 (print); 2614-350X (online)

Vol.9 No.2 November 2020 Page.381-391

many as $35(43.2 \%)$ not exclusive breastfeeding. Employment of the majority of unemployed mothers as many as $74(91.4 \%)$ gave exclusive breastfeeding and $63(77.8 \%)$ did not exclusively breastfeed.

2. The percentage of infants aged 6-12 months who were given exclusive breastfeeding was 81 $(50.0 \%)$ of respondents and not exclusive breastfeeding was $81(50.0 \%)$ of respondents.

3. Frequency of illness occurrence in infants aged 6-12 months who were given exclusive breastfeeding, the majority experienced a frequency of infrequent sickness events as many as $59(72.8 \%)$ respondents and non-exclusive breastfeeding, the majority experienced frequency of illness events that were often as many as $50(61.7 \%)$ respondent.

4. There is a relationship between exclusive breastfeeding and the frequency of illness in infants aged 6-12 months at the Banyumas Health Center $(\mathrm{p}=.000<0.05)$.

\section{REFERENCE}

Andriyani, A. (2013). ASI As Natural Immunization. Yogyakarta: Muslim Reader.

Ara, M. A. (2018). Differences in Growth and Immunity Status of Infants 6-12 Months Based on Breastfeeding in the Work Area of the Ngkeran Health Center in Southeast Aceh District 2017. University of North Sumatra. Picked October 15, 2019, from http://repositori.usu.ac.id/handle/123456789/6641

Azkia, H. (2019). Acquaintance with Pneumonia. Yogyakarta: Kemochi Media.

Central Bureau of Statistics. (2018). 2018 Maternal and Child Health Profile. Picked January 11, 2020 , from https://www.bps.go.id/publication/2018/11/15/23aade2096f222222b1d7b7a/profil-k Kesehatan-ibu-dan-anak-2018.html

Choyron, V. A., Raharjo, B., \&Werdani, K. E. (2015). The Relationship of Exclusive Breastfeeding with the Incidence of Pneumonia in Toddlers in the PedanKlatenPuskesmas Work Area. Muhammadiyah University of Surakarta.

Dewi, P. S. (2017). Working Mothers and Non-Working Mothers In Exclusive breastfeeding in Karangpakis Village, Kec. Kabuh, Kab. Jombang. Midwifery Journal Of STIKES Insan Scholar MedikaJombang.

Dharma, K. K. (2011). Nursing Research Methodology (Guidelines for Implementing and Implementing Research Results). East Jakarta: CV. Trans Info Media.

Banyumas District Health Office. (2019). Health Profile of 2018 Banyumas Regency. Picked January 12, 2020, from http://dinkes.banyumaskab.go.id/read/28410/profil-kempuantahun-2018-kab--anyanyumas\#.XhscY7kxeyX

Fadhilah, D. (2018). The Relationship Between Exclusive Breastfeeding and Reduction in Occurrence of Infection in Infants 6-12 Months in Mlati II Health Center. Health Polytechnic of the Yogyakarta Ministry of Health.

Gunawan, K. (2010). ARI Prevention and Management. Semarang: Provincial Health Office of Central Java.

Hakim, N. L. (2018). The Relationship of Exclusive Breastfeeding with the Low Frequency of Fever Occurrence in 1-Year Old Babies at Hakim Medika Clinic, Pandanwangi Village, Tempeh District, Lumajang Regency. Wijaya University

Handy, F. (2016). A-Z Subscribed Children's Disease. Jakarta: PuspaSwara.

Hanifah, S. A. (2015). Characteristics of Breastfeeding Mothers Not Providing Exclusive Breastfeeding in Cikeruh Village, Jatinangor District, Sumedang Regency in 2015. Padjadjaran University.

Hardiyanti, T. P., \& Abdullah, A. (2019). Relationship between acute otitis media and breastfeeding in children. Yogyakarta Muhammadiyah University.

Haryono, R., \&Setianingsih, S. (2014). Benefits of Exclusive Breastfeeding for Your Baby Yogyakarta: GasyenPublising.

Kapti, R. E., \&Azizah, N. (2017). Care of Sick Children at Home. Malang: UBPres. 


\section{STRADA Jurnal Ilmiah Kesehatan}

DOI: $10.30994 /$ sjik.v9i2.311

ISSN: 2252-3847 (print); 2614-350X (online)

Vol.9 No.2 November 2020 Page.381-391

The Indonesian Ministry of Health. (2015). Indonesia Health Profile 2015. Picked November 17, 2019, from ttps: //www.kemkes.go.id/resources/download/pusdatin/profil-kempuanindonesia/profil-kempuan-Indonesia-2015.pdf

Lestari, C. I. (2019). Factors That Cause Failure of Mothers in Providing Exclusive Breastfeeding to Infants Age 0-6 Months in Pejeruk Health Center Work Areas. Muhammadiyah University of Mataram.

Maki, F., Umboh, A., \&Ismanto, A. Y. (2017). Differences in Exclusive Breastfeeding and Formula Milk for Diarrhea Occurrence in Infants 6-12 Months in the RanotanaWeru Health Center. eJournal of Nursing (eKp).

Maryunani, A. (2010). Children's Health Sciences in Midwifery. Jakarta: CV. Trans Info Media.

Mindarsih, E. (2018). Husband's Characteristics Associated with Attitudes in Handling Maternal and Neonatal Emergency. Respati Nursing Journal Yogyakarta.

Mujib, A. (2018). The Relationship between Diarrhea and the Provision of Breast Milk Substitute (PASI) for Infants (0-6 months) (In the Neonatal Room of RSI Sakinah Mojokerto). STIKES Insan Scholar MedikaJombang. Posted March 8, 2020, from http://repo.stikesicme-jbg.ac.id/1869/

Mulyani, S., \&Astuti, M. (2018). Factors Associated with Exclusive Breastfeeding in the Working Area of the Health Clinic in the City of Jambi. University of Jambi Scientific Applied Scientific Journal.

Nangi, M. G., Yanti, F., \& Lestari, S. A. (2019). Basic Epidemiology. Yogyakarta: Deepublish.

Narwastu, H. K. (2019). The Relationship of Exclusive Breastfeeding with the Incidence of Pneumonia in Toddlers in Bergas Health Center, Semarang Regency. NgudiWaluyo University Ungaran.

Ningsih, A. N. (2017). The Relationship of Exclusive Breastfeeding with the Incidence of Diarrhea in Infants in PuskesmasUmbulharjo 1 Yogyakarta City in 2016. Ministry of Health's Health Polytechnic.

Notoatmodjo. (2010). Health Research Methodology. Jakarta: RinekaCipta.

Nurbayanti, E. S. (2016). Characteristics of mothers related to exclusive breastfeeding at the PusonTemon II KulonProgo Yogyakarta. Universitas' Aisyiyah Yogyakarta.

Nurlaila, Utami, W., \&Cahyani W, T. (2018). Children's Nursing Textbooks. Yogyakarta: LeutikaPrio.

Pitriani, \&Herawanto. (2019). Textbook on Environmental Health Epidemiology. Makassar: Nas Media Library.

Pratiwi, W. M., \&Taufiqa, Z. (2017). Breastfeeding Mother's Smart Diary and MP-ASI. Jakarta: Gramedia.

Priyono, Y. (2010). Caring for Babies Without a Baby Sister. Yogyakarta: Media Pressindo.

Proverawati, A., \&Rahmawati, E. (2010). Capita Selekta ASI and Lactation. Yogyakarta: NuhaMedika.

Purba, E. M., Manurung, H. R., \&Sianturi, N. (2020). The Relationship between Mother's Characteristics and Exclusive Breastfeeding in the Work Area of the Korpri Health Center in the District of Berastagi, Karo Regency in 2019. CHMK Health Journal.

Purwanti, H. S. (2014). The Concept of Implementing Exclusive ASI. Jakarta: EGC.

Rajab, W. (2009). Buju Teaches Epidemiology For Midwifery Students. Jakarta: EGC.

Rajab, W., Fratidhina, Y., \&Fauziah. (2018). Basic Concepts of Midwifery Skills. Malang: Wineka Media.

Riyanto, S., \&Hatmawan, A. A. (2020). Research Methods Quantitative Research Research in the Field of Management, Engineering, Education and Experiments. Yogyakarta: Deepublish.

Rukajat, A. (2018). Quantitative Research Approaches: Quantitative Research Approach. Yogyakarta: Deepublish.

Sari, Y. P. (2017). Relationship of Exclusive Breastfeeding with Common Cold Occurrence in Infants 6-12 Months in the Kartasura Health Center Area. Muhammadiya University Surakarta. 


\section{STRADA Jurnal Ilmiah Kesehatan}

DOI: $10.30994 /$ sjik.v9i2.311

ISSN: 2252-3847 (print); 2614-350X (online)

Vol.9 No.2 November 2020 Page.381-391

Saryono (2011). Health Research Methodology Practical Guide for Beginners Cet.IV. Jogjakarta: Mitra Cendikia Press.

Sastroasmoro, S. (2011). Fundamentals of Clinical Research Methodology. Jakarta: SagungSeto.

Savitri, D. (2018). Factors Related to Exclusive Breastfeeding in Karanganyar District Karanganyar District. Muhammadiyah Surakarta university.

Sentana, K. A., Adnyana, I. A., \&Subanada, I. B. (2018). Relationship of exclusive breastfeeding with the incidence of diarrhea in infants. Medika E-Journal.

Setyawan, F. E. (2019). Family Physician Health Service Approach (Comprehensive Holistic Approach). Sidoarjo: ZifatamaJawara.

Sihombing, S. (2018). The Relationship between Mother's Work and Education with Exclusive Breastfeeding in the Work Area P

Singh (2017). The Relationship between Exclusive Breastfeeding and Diarrhea Incidence in Children aged 6-24 months. University of North Sumatra.

Sirait, S. H. (2017). The effect of exclusive breastfeeding with the occurrence of ARI in young children at the Singosari Public Health Center in Pematangsiantar City. Global Health Science.

Sohimah, \& Lestari, Y. A. (2017). Analysis of Factors Affecting Exclusive Breastfeeding (ASI) in the Work Area of the Cilacap Tengah I Health Center in the District of Cilacap in 2017. STIKES Al-Irsyad Al-IslamiyyahCilacap.

Sugani, S., \& Lucia, P. (2010). The Smart Way To Be Healthy: The Secret To Healthy Life Without A Doctor. Jakarta: Transmedia.

Sumampouw, O. J. (2017). Eradication of Communicable Diseases. Yogyakarta: Deepublish.

Susanti, T. I., Wigunantiningsih, A., \&Hastutik. (2015). Difference in the Frequency of Diarrhea in Babies Given Exclusive Breastfeeding and Babies Not Exclusive Breastfeeding in the Work Area of KaranganyarJaten I Health Center. Maternal

Umar, H. (2019). Company Management Research Methods Quick and Appropriate Steps to Arrange Thesis and Dissertation. Jakarta: Gramedia Main Library.

UNICEF. (2019). Infant and Young Child Feeding. Picked January 10, 2020, from https://data.unicef.org/topic/nutrition/infant-and-young-child-feeding/

UNICEF. (2019). Under-five mortality. Retrieved January 10, 2020, from https://data.unicef.org/topic/child-survival/under-five-mortality/ 


\section{STRADA Jurnal Ilmiah Kesehatan}

DOI: $10.30994 /$ sjik.v9i2.311

ISSN: 2252-3847 (print); 2614-350X (online)

Appendix Table

Univariate Variable

Table 1

Characteristics of Respondents

Frequency Distribution of Characteristics of Infants Mothers Aged 6-12 Months at Banyumas Health Center in $2020(\mathrm{n}=162)$

\begin{tabular}{|c|c|c|c|c|}
\hline \multirow{3}{*}{ Characteristics } & \multicolumn{4}{|c|}{ Giving Breastfedding } \\
\hline & \multicolumn{2}{|c|}{ Exclusive Breastfedding } & \multicolumn{2}{|c|}{ No Exclusive Breastfedding } \\
\hline & $\mathrm{n}=81$ & $\%$ & $\mathrm{n}=81$ & $\%$ \\
\hline \multicolumn{5}{|l|}{ Age } \\
\hline$<20$ year & 1 & 1,2 & 3 & 3,7 \\
\hline 20-35 year & 73 & 90,1 & 65 & 80,2 \\
\hline$>35$ year & 7 & 8,6 & 13 & 16,0 \\
\hline Count & 81 & 100,0 & 81 & 100,0 \\
\hline \multicolumn{5}{|l|}{ Graduation } \\
\hline Primary School & 13 & 16,0 & 7 & 8,6 \\
\hline Junior high school & 32 & 39,5 & 28 & 34,6 \\
\hline Senior high scool & 25 & 30,9 & 35 & 43,2 \\
\hline College & 11 & 13,6 & 11 & 13,6 \\
\hline Count & 81 & 100,0 & 81 & 100,0 \\
\hline \multicolumn{5}{|l|}{ Proffesion } \\
\hline No Work & 74 & 91,4 & 63 & 77,8 \\
\hline The Farmer & 0 & 0,0 & 1 & 1,2 \\
\hline Entrepeuner & 3 & 3,7 & 7 & 8,6 \\
\hline Non Formal & 4 & 4,9 & 9 & 11,1 \\
\hline Governmen employees & 0 & 0,0 & 1 & 0,0 \\
\hline Count & 81 & 100,0 & 81 & 100,0 \\
\hline
\end{tabular}

Table 2: Frequency Distribution of Exclusive Breastfeeding for 6-12 Months Infants at Banyumas Health Center in $2020(\mathrm{n}=162)$

\begin{tabular}{lcc} 
Giving Exclusive Breastfeeding & N & $\%$ \\
\hline Exclusive Breastfeeding & 81 & 50,0 \\
No Exclusive Breastfeeding & 81 & 50,0 \\
Count & 162 & 100,0 \\
\hline
\end{tabular}

Table 3: Frequency Distribution of Sickness in Infants 6-12 Months at Banyumas Health Center in $2020(\mathrm{n}=162)$

Frequency of illness $\quad$ Giving Exclusive Breastfeeding

\begin{tabular}{lcccc} 
& \multicolumn{2}{c}{ Exclusive Breastfeeding } & \multicolumn{2}{c}{ No Exclusive Breastfeeding } \\
\cline { 2 - 5 } & $\mathrm{n}=81$ & $\%$ & $\mathrm{n}=81$ & $\%$ \\
\hline Rarely sick & 59 & 72,8 & 31 & 38,3 \\
Often sick & 22 & 27,2 & 50 & 61,7 \\
Count & 81 & 100,0 & 81 & 100,0
\end{tabular}




\section{STRADA Jurnal Ilmiah Kesehatan}

DOI: $10.30994 /$ sjik.v9i2.311

ISSN: 2252-3847 (print); 2614-350X (online)

Vol.9 No.2 November 2020 Page.381-391

Bivariate Variable

Table 4: Relationship of Exclusive Breastfeeding to Frequency of Occurrence of Pain in Infants 612 Months in Banyumas Health Center in $2020(n=162)$

\begin{tabular}{|c|c|c|c|c|c|c|}
\hline \multirow{3}{*}{ Giving Exclusive Breastfeeding } & \multicolumn{4}{|c|}{ Frequency of illness } & \multirow{3}{*}{$p$-value } & \multirow{3}{*}{ RR } \\
\hline & \multicolumn{2}{|c|}{ Rarely sick } & \multicolumn{2}{|c|}{ Often sick } & & \\
\hline & $\mathrm{N}$ & $\%$ & $\mathrm{~N}$ & $\%$ & & \\
\hline Exclusive Breastfeeding & 59 & 72,8 & 22 & 27,2 & & \\
\hline No Exclusive Breastfeeding & 31 & 38,3 & 50 & 61,7 & ,000 & 1,903 \\
\hline Count & 90 & 55,6 & 72 & 44,4 & & \\
\hline
\end{tabular}

